\title{
Strain differences in passive avoidance conditioning in the rat
}

\author{
GORDON M. HARRINGTON \\ University of Northern Iowa, Cedar Falls, Iowa 50613
}

\begin{abstract}
One-trial passive avoidance conditioning was carried out in a step-through apparatus for 480 rats from 12 inbred strains: ACI, A990, A35322, F344, INR, IR, MNR/Har, MNRA, MR/Har, TS1, TS3, WAG. The results provide parametric data for methodological use and add to the standardization of these strains as behaviorally defined lines.
\end{abstract}

In reviewing the behavior genetic literature, Lindzey, Loehlin, Manosevitz, and Thiessen (1971) observed that "of all learning studies, avoidance conditioning studies have been the most popular." With respect to genetic variation, there exists a substantial body of avoidance work with respect to both the mouse and the rat. However, the rat data, unlike those for the mouse, have concentrated on active avoidance paradigms, with minimal attention to the phenomena of passive avoidance. In the present study, strain differences in one-trial passive avoidance conditioning are examined for those 12 genetically defined lines of rats having the highest citation in the behavioral literature. It is one of a number of studies (Harrington, 1971a, 1971b, 1972, 1979a, 1979b, 1979c, 1979d, 1979e, 1979f, 1979g, 1979h; Harrington \& Hellwig, 1979a, 1979b) intended to provide behavioral standardization data for those strains motivated in part by the general interdisciplinary concern in recent years for precise specification and standardization of lines of laboratory animals (International Committee on Laboratory Animals, 1971).

\section{METHOD}

\section{Subjects}

Subjects were 480 rats 114-128 days of age, 20 of each sex from each of the following 12 inbred strains: $A C I / H a r$, A990/Har, A35322/Har, F344/DuHar, INR, IR, MR/Har, MNR/Har, MNRA (formerly MNR-a/Har), TS1, TS3, WAG/Har. All lines are designated by the standard nomenclature for this species and are described in the fourth international listing (Festing \& Staats, 1973). Animals were bred and maintained at $25.5^{\circ} \mathrm{C} \pm 1.1^{\circ} \mathrm{C}$ and $40 \% \pm 5 \%$ relative humidity. Breeders and pups were housed under natural light cycle. Pups were handled for $1 \mathrm{~min}$ on alternate days from age 14 to 45 days. At 45 days, they were transferred to individual cages with 24-h light cycle. More detailed descriptions are available elsewhere (Harrington, 1968).

\section{Apparatus}

The apparatus was an enlarged version of that described by Jarvik and Kopp (1967). It was a box with vertical end panels and a V cross section, the longitudinal walls converging to a narrow floor approximately the width of a rat. A longitudinal gap divided the floor. Floor and walls were covered with metal plates that could be switched either to serve as sensors or to administer shock. The box was divided into a larger dark compartment and a smaller light compartment by a lateral wall with a hole of sufficient size for a rat to pass through. The light compartment was illuminated from the top by a $100-\mathrm{W}$ bulb. The apparatus subsequently was lost in a fire, so that detailed measurements are no longer available.

Each subject was placed in the light compartment and allowed to pass through into the dark compartment. When the animal had fully entered the dark compartment as detected by sensor use of the plates, $50-\mathrm{V}$ ac matched-impedance shock was automatically administered. Animals were removed from the apparatus immediately following escape back into the light compartment. All subjects entered the dark compartment and escaped. Subjects were again placed in the light compartment $24 \mathrm{~h}$ later for $90 \mathrm{sec}$, and latency to enter the dark compartment was automatically recorded. Failures to enter the dark compartment were arbitrarily scored as $90 \mathrm{sec}$.

\section{RESULTS AND DISCUSSION}

The means and standard deviations of times to enter the dark compartment on the second day are shown in Table 1. The ACI, A35322, and TS1 strains stand out as most conditionable in this passive avoidance task, while the IR and MR lines showed least evidence of conditioning. For the design of experiments where

Table 1

Passive Avoidance of a Dark Chamber $24 \mathrm{~h}$ Following One Trial with Shock

\begin{tabular}{lccccc}
\hline & \multicolumn{4}{c}{ Latency to Enter* } \\
\cline { 2 - 3 } \multicolumn{1}{c}{ Strain } & \multicolumn{2}{c}{ Males } & & Females \\
\cline { 2 - 3 } \cline { 5 - 6 } Mean & SD & & Mean & SD \\
\hline ACI/Har & 90.0 & 0.0 & 85.4 & 19.0 \\
A990/Har & 61.8 & 38.8 & 56.9 & 34.5 \\
A35322/Har & 71.9 & 29.7 & 84.9 & 13.8 \\
F344/DuHar & 44.7 & 36.0 & 57.0 & 37.1 \\
INR & 60.6 & 33.0 & 45.9 & 32.8 \\
IR & 18.5 & 29.9 & 17.0 & 30.4 \\
MNR/Har & 49.4 & 34.8 & 60.0 & 34.5 \\
MNRA & 64.8 & 35.0 & 67.0 & 34.8 \\
MR/Har & 28.6 & 29.1 & 16.3 & 22.9 \\
TS1 & 80.2 & 25.6 & 83.9 & 19.4 \\
TS3 & 63.8 & 36.3 & 72.8 & 32.6 \\
WAG/Har & 74.0 & 29.4 & 69.2 & 32.8 \\
\hline
\end{tabular}

Note $-N=20$ for each sex within each strain.

*90 sec maximum. 
control of such conditionability would increase precision, these would appear to be the animals of preference.

Insofar as strain differences are concerned, there appears to be no relationship between passive avoidance conditionability as measured by step-through latency and emotionality as measured by open-field defecation. Comparing these results with previously reported defecation data (Harrington, 1972), the Spearman rank-difference correlations of strain means of latencies and of defecation were -.01 for males and .14 for females. The question remains open as to whether or not these measures are correlated for individuals rather than for strains.

\section{REFERENCES}

Festing, M., \& StaAts, J. Standardized nomenclature for inbred strains of rats. Transplantation, 1973, 16, 221-245.

HARRINGTON, G. M. Genetic-environmental interaction in "intelligence." I: Biometric genetic analysis of maze performance of Rattus Norvegicus. Developmental Psychobiology, 1968, 1, 211-218.

HARRINGTON, G. M. Strain differences among rats initiating exploration of differing environments. Psychonomic Science, 1971, 23, 348-349 (a).

HaRrington, G. M. Strain differences in rotating wheel activity of the rat. Psychonomic Science, 1971, 23, 363-364. (b)

HARRINGTon, G. M. Strain differences in open field behavior of the rat. Psychonomic Science, 1972, 27, 51-53.

HARRINGton, G. M. Strain differences in activity of the rat in a shuttle stabilimeter. Bulletin of the Psychonomic Society, 1979, 13, 149-150 (a).
Harrington, G. M. Strain differences in activity of the rat using a home cage stabilimeter. Bulletin of the Psychonomic Society, 1979, 13, 151-152. (b)

HARRINGTON, G. M. Strain differences in free operant leverpress levels in the rat. Bulletin of the Psychonomic Society, 1979, 13, 153-154. (c)

HARRINGton, G. M. Strain differences in light-contingent barpress behavior of the rat. Bulletin of the Psychonomic Society, 1979, 13, 155-156. (d)

HARRINGTON, G. M. Strain differences in open-field behavior of the rat. II. Bulletin of the Psychonomic Society, 1979, 13, 85-86. (e)

HARRINGton, G. M. Strain differences in runway learning in the rat. Bulletin of the Psychonomic Society, 1979, 13, 159-160. (f)

HARRINGTON, G. M. Strain differences in shuttle avoidance conditioning in the rat. Bulletin of the Psychonomic Society, 1979, 13, 161-162. (g)

HARRINGTON, G. M. Strain differences in simple operant barpress acquisition to an auditory stimulus by rats. Bulletin of the Psychonomic Society, 1979, 13, 163-164. (h)

Harrington, G. M., \& Hellwig, L. R. Strain differences in basal metabolism of behaviorally defined rats. Bulletin of the Psychonomic Society, 1979, 13, 165-166. (a)

Harrington, G. M., \& Hellwig, L. R. Strain differences in organ weights of behaviorally defined rats. Bulletin of the Psychonomic Society, 1979, 13, 167-169. (b)

International Committee on Laboratory Animals. Defining the laboratory animal. Washington, D.C: National Academy of Sciences, 1971.

JARVIK, M. E., \& KopP, R. An improved one-trial passive avoidance learning situation. Psychological Reports, 1967, 21, 221-224.

Lindzey, G., Loehlin, J., Manosevitz, M., \& Thiessen, D. Behavior genetics. Annual Review of Psychology, 1971, 22, 39-94.

(Received for publication January 16, 1979.) 